\title{
KONSEP PERBUATAN MELAWAN HUKUM DALAM TINDAK PIDANA
}

\section{TITIN APRIANI}

\author{
Fakultas Hukum Universitas Mahasaraswati Mataram
}

e-mail: titinapriani91@gmail.com

\begin{abstract}
ABSTRAK
Tujuan dari penelitian ini adalah untuk mengetahui : (a), apakah suatu perbuatan tindak pidana bisa dikatakan suatu perbuatan melawan hukum. (b). bagaimana bentuk penerapan hukum antara suatu perbuatan melawan hukum dengan perbuatan tindak pidana. Penelitian ini bermanfaat untuk memberikan bekal pengetahuan dalam mengkaji atau menerapkan suatu ilmu pengetahuan hukum khususnya perbuatan melawan hukum, hukum pidana, hukum acara pidana, melalui suatu tindakan empiris di lapangan/masyarakat. Sedangkan secara praktis, bahwa hasil peneltian ini akan dapat dimanfaatkan sebagai suatu masukan atau sumbangan pemikiran bagi pejabat / aparat terkait untuk meningkatkan kualitas pelaksanaan tugas, khususnya dalam penerapan peraturan hukum yang berlaku bagi kasus-kasus serupa. Hasil penelitian menunjukkan bahwa pemahaman tentang perbuatan melawan hukum lebih banyak dikemukakan oleh para ahli. Dari sekian banyak ahli yang merumuskan pengertian dari perbuatan melawan hukum (PMH) yang satu sama lainnya akan berbeda, sehingga untuk memahaminya secara materil kita membutuhkan unsur-unsur untuk menggolongkan suatu perbuatan tertentu masuk ke dalam PMH atau tidak. Sehingga dengan adanya unsur-unsur tersebut diharapkan terciptanya satu pemahaman mengenai pengertian dari perbuatan melawan hukum tersebut.
\end{abstract}

Kata kunci :Tindak pidana, Perbuatan melawan hukum

\section{ABSTRACT}

The purpose of this study is to find out: (a), whether an act of crime can be said to be an act against the law. (b). what form of law is applied between an act against the law and an act of crime. This research is useful to provide knowledge in reviewing or applying a legal science specifically acts against the law, criminal law, criminal procedure law, through an empirical action in the field / society. While practically, the results of this study will be utilized as an input or contribution to the thought of officials / related officials to improve the quality of the implementation of tasks, especially in the application of applicable legal regulations for similar cases. The results of the study show that the understanding of acts against the law is more often expressed by experts. Of the many experts who formulated the notions of unlawful acts $(P M H)$ with each other will be different, so to understand them materially we need elements to classify a particular act into PMH or not, so that the existence of these elements is expected to create an understanding of notion of acts against the law.

Keywords: Crime, Unlawful acts

\section{PENDAHULUAN}

\section{Latar Belakang}

Dalam kehidupannya manusia memiliki hak dan kewajiban yang saling berhubungan dan bahkan saling berbenturan. Adanya perbedaan keinginan dan kebutuhan menciptakan perbedaan pula dalam hal hak dan kewajiban. Akibatnya terjadilah benturan-benturan kepentingan yang dapat menguntungkan maupun yang dapa merugikan. Dalam hal ini setiap manusia, sebagai makhluk sosial yang berakal budi, tentunya harus saling menghargai hak dan kewajiban setiap individu. Dan untuk mempertegas dan memperjelas hal itu, terciptalah berbagai aturan, baik tertulis maupun tidak tertulis, yang disepakati untuk ditaati bersama demi kelancaran dan kenyamanan kehidupan umat manusia. 
Namun hal ini tidaklah semudah yang dibayangkan, karena dalam praktek kehidupan sehari-hari, ada ketidakmampuan dan atau kesengajaan untuk melanggar aturan yang telah disepakati tersebut. Maka terciptalah kekacauan, keadaan yang tidak menyenangkan, keadaan yang mengakibatkan ketimpangan pemenuhan hak dan kewajiban dan lain sebagainya. Dalam keadaan seperti ini terjadilah desakan kekuatan aturan yang ada yang berupa sanksi-sanksi atas mereka yang tidak mampu memenuhi dan atau sengaja melanggar aturan-peraturan yang ada. Artinya, disinilah berperan hukum dan perangkat-perangkat yang ada.

Didalam mengkaji hukum, kita akan mememukan istilah perbuatan melawan hukum yaitu, suatu perbuatan yang menimbulkan kerugian terhadap pihak-pihak lain sehingga adanya gugatan dari pihak-pihak tersebut. Perbuatan melawan hukum memiliki dua perspektif, yang pertama adalah perbuatan melawan hukum dalam perspektif hukum pidana, dan yang kedua perbuatan melawan hukum dalam perspektif hukum perdata. Dalam karya ilmiah ini, penulis akan menitik beratkan pengkajian terhadap perbuatan melawan hukum dalam perspektif hukum pidana yaitu : konsep perbuatan melawan hukum dalam perbuatan tindak pidana.

\section{Rumusan Masalah}

1. Apakah suatu perbuatan tindak pidana dapat dikatakan suatu perbuatan melawan hukum?

2. Bagaimanakan penerapan hukuman antara perbuatan melawan hukum dengan perbuatan tindak pidana?

\section{METODE PENELITIAN}

Jenis Penelitian ini merupakan penelitian normatif karena penelitian ini menitik beratkan pada penelitian secara menyeluruh, sistematis, faktual dan aktual mengenai fakta-fakta yang berhubungan dengan masalah yang akan diteliti.Pelaksanaan penelitian ini melalui tahap penelitian kepustakaan guna mendapatkan data sekunder.

Metode pendekatan yang dipergunakan dalam penelitian ini adalah pendekatan perundang-undangan (the statute approach) dan pendekatan historis (historical approach) yaitu menguraikan latar belakang, sejarah maupun beberapa unsure-unsur penyesesaian yang dipergunakan.

Pendekatan konseptual (conceptual approach) yaitu memanfaatkan pandangan dan pemikiran para ahli yang berkenan dengan konsep perbuatan melawan hukum serta konsep perbuatan tindak pidana.

\section{HASIL PENELITIAN DAN PEMBAHASAN}

\section{Apakah suatu perbuatan tindak pidana dapat dikatakan suatu perbuatan melawan hukum.}

Pengertian perbuatan melawan hukum di dalam KUHPerdata secara yuridis tidak dijelaskan secara gamblang. Namun demikian dalam KUHPerdata terdapat pasal-pasal yang secara limitatif mengatur akibatakibat yuridis dalam hal terjadinya perbuatan melawan hukum. Dalam perkembangan ilmu dan teori mengenai hukum, pengertian dan pemahaman tentang perbuatan melawan hukum lebih banyak dikemukakan oleh para ahli. Dari sekian banyak ahli yang merumuskan pengertian dari perbuatan melawan hukum (PMH) yang satu sama lainnya akan berbeda, sehingga untuk memahaminya secara materil kita membutuhkan unsur-unsur untuk menggolongkan suatu perbuatan tertentu masuk kedalam PMH atau tidak. Sehingga dengan adanya unsur-unsur tersebut diharapkan terciptanya satu pemahaman mengenai pengertian dari perbuatan melawan hukum tersebut dan diharapkan dapat menciptakan kepastian hukum.

Dalam konteks hukum pidana, menurut pendapat dari Satochid Kartanegara, "melawan hukum" (Wederrechtelijk) dalam hukum pidana dibedakan menjadi:

a. Wederrechtelijk formil, yaitu apabila sesuatu perbuatan dilarang dan diancam dengan hukuman oleh undang-undang.

b. Wederrechtelijk Materiil, yaitu sesuatu perbuatan "mungkin" wederrechtelijk, walaupun tidak dengan tegas dilarang dan diancam dengan hukuman oleh undang-undang. Melainkan juga asas-asas umum yang terdapat di dalam lapangan hukum (algemen beginsel).

Lebih lanjut, Schaffmeister sebagaimana dikutip oleh andi hamzah dalam bukunya"Pengantar dalam hokum pidana Indonesia", hal. 168. Berpendapat bahwa "melawan hokum"yang tercantum di dalam rumusan delik yang menjadi bagian inti delik sebagai "melawan hokum secarak khusus" contohnya Pasal 372 Kitab 
Undang-undang Hukum Pidana atau KUHP. Sedangkan melawan hokum sebagai unsur yang tidak disebut dalam rumusan delik tetapi menjadi dasar untuk menjatuhkan pidana sebagai melawan hokum secara umum. (contoh Pasal 351 KUHP). Pendapat dari schaffmeister ini bener-bener diterapkan dalam hokum positif di Indonesia.

Salah satu unsur dari tindak pidana adalah unsur tindakan melawan hukum. Unsur ini merupakan suatu penilaian obyektif terhadap perbuatan dan bukan terhadap si pembuat. Sesuatu perbuatan dikatakan melawan hukum apabila perbuatan itu masuk dalam rumusan delik sebagaimana dirumuskan dalam undang-undang. Dalam bahasa Jerman ini disebut "tatbestandsmaszig". Selain istilah tersebut, perbuatan melawan hukum juga dikenal dengan perkataan "wederrechtelijk", yang menurut Profesor van Hamel sebagaimana dikutip oleh P.A.F. Lamintang, sudah tepat dan mempunyai arti yang positif, bahwa lebih baik dari pada penggunaan perkataan "onrechtmatig", oleh karena perkataan tersebut cocok dipergunakan sebagai "ephiteton" atau kata keterangan bagi tindakan-tindakan yang dilarang dan diancam dengan hukuman, karena telah ditujukan untuk mengancam atau menyerang kepentingan-kepentingan hukum, baik yang bersifat umum, maupun yang bersifat khusus. Oleh karena itu, penggunaan perkataan wederrechtelijk tersebut sebenarnya telah mempunyai dasar yang kuat, baik menurut tata bahasa maupun secara logis.

Simon mengatakan bahwa pendapat van Hamel mengenai wederrichtelijk mempunyai arti positif, adalah tidak benar. Sebagai alasan telah dikemukakannya bahwa apabila orang mengambil contoh dari bunyi Pasal 378 KUHP itu saja misalnya, maka pemberian arti berbeda akan memberikan hasil yang berbeda-beda pula. Dikaji dari perspektif teoretis dan praktik konsepsi perbuatan melawan hukum dikenal dalam dimensi hukum perdata dan hukum pidana. Dari aspek etimologis dan terminologis maka perbuatan melawan hukum dalam bahasa Belanda dikenal dengan terminologi "wederrechtelijk" dalam ranah hukum pidana dan terminologi "onrechtmatige daad" dalam ranah hukum perdata. Akan tetapi, pengertian dan terminologi wederrechtelijk dalam hukum pidana tersebut ada diartikan sebagai bertentangan dengan hukum (in strijd met hetrecht), atau melanggar hak orang lain (met krenking van eens anders recht) dan ada juga yang mengartikan sebagai tidak berdasarkan hokum (niet steunend op het recht) atau sebagai tanpa hak (zonder bevoegheid).

Perbuatan yang memenuhi rumusan delik (tatbestandsmazig), tidak senantiasa bersifat melawan hukum, sebab ada hal yang menghilangkan sifat melawan hukumnya perbuatan tersebut, misalnya: Regu penembak, yang menembak mati seorang terhukum yang telah dijatuhi pidana mati, memenuhi unsur-unsur delik tersebut Pasal 338 KUHP. Perbuatan mereka tidak melawan hukum, karena mereka menjalankan perintah jabatan yang sah (Pasal 51 ayat $1 \mathrm{KUHP}$ ).

Jaksa menahan orang yang sangat dicurigai telah melakukan kejahatan. Ia tidak dapat dikatakan melakukan kejahatan tersebut Pasal 333 KUHP, karena ia melaksanakan undang-undang (terdapat dalam peraturan hukum acara pidana), sehingga tidak ada unsur melawan hukum) (Pasal 50 KUHP).

Berkaitan dalam asas hukum pidana yaitu Geen straf zonder schuld, actus non facit reum nisi mens sir rea, bahwa tidak dipidana jika tidak ada kesalahan, maka pengertian tindak pidana itu terpisah dengan yang dimaksud pertanggungjawaban tindak pidana. Tindak pidana hanyalah menunjuk kepada dilarang dan diancamnya perbuatan itu dengan suatu pidana, kemudian apakah orang yang melakukan perbuatan itu juga dijatuhi pidana sebagaimana telah diancamkan akan sangat tergantung pada soal apakah dalam melakukan perbuatannya itu si pelaku juga mempunyai kesalahan.

Dalam kebanyakan rumusan tindak pidana, unsur kesengajaan atau yang disebut dengan opzet merupakan salah satu unsur yang terpenting. Dalam kaitannya dengan unsur kesengajaan ini, maka apabila didalam suatu rumusan tindak pidana terdapat perbuatan dengan sengaja atau biasa disebut dengan opzettelijk, maka unsur dengan sengaja ini menguasai atau meliputi semua unsur lain yang ditempatkan dibelakangnya dan harus dibuktikan. Sengaja berarti juga adanya kehendak yang disadari yang ditujukan untuk melakukan kejahatan tertentu. Maka berkaitan dengan pembuktian bahwa perbuatan yang dilakukannya itu dilakukan dengan sengaja, terkandung pengertian menghendaki dan mengetahui atau biasa disebut dengan willens en wetens. Yang dimaksudkan disini adalah seseorang yang melakukan suatu perbuatan dengan sengaja itu haruslah memenuhi rumusan willens atau haruslah menghendaki apa yang ia perbuat dan memenuhi unsur wettens atau haruslah mengetahui akibat dari apa yang ia perbuat.

Disini dikaitkan dengan teori kehendak yang dirumuskan oleh Von Hippel maka dapat dikatakan bahwa yang dimaksudkan dengan sengaja adalah kehendak membuat suatu perbuatan dan kehendak untuk menimbulkan suatu akibat dari perbuatan itu atau akibat dari perbuatannya itu yang menjadi maksud dari dilakukannya perbuatan itu. Jika unsur kehendak atau menghendaki dan mengetahui dalam kaitannya dengan unsur kesengajaan tidak dapat dibuktikan dengan jelas secara materiil karena memang maksud dan kehendak seseorang itu sulit untuk dibuktikan secara materiil maka pembuktian adanya unsur kesengajaan dalam 
pelaku melakukan tindakan melanggar hukum sehingga perbuatannya itu dapat dipertanggungjawabkan kepada si pelaku seringkali hanya dikaitkan dengan keadaan serta tindakan si pelaku pada waktu ia melakukan perbuatan melanggar hukum yang dituduhkan kepadanya tersebut.

Disamping unsur kesengajaan di atas ada pula yang disebut sebagai unsur kelalaian atau kealpaan atau culpayang dalam doktrin hukum pidana disebut sebagai kealpaan yang tidak disadari atau onbewuste schuld dan kealpaan disadari atau bewuste schuld. Dimana dalam unsur ini faktor terpentingnya adalah pelaku dapat menduga terjadinya akibat dari perbuatannya itu atau pelaku kurang berhati-hati.

Wilayah culpa ini terletak diantara sengaja dan kebetulan. Kelalaian ini dapat didefinisikan sebagai apabila seseorang melakukan sesuatu perbuatan dan perbuatan itu menimbulkan suatu akibat yang dilarang dan diancam dengan hukuman oleh undang-undang, maka walaupun perbuatan itu tidak dilakukan dengan sengaja namun pelaku dapat berbuat secara lain sehingga tidak menimbulkan akibat yang dilarang oleh undang-undang, atau pelaku dapat tidak melakukan perbuatan itu sama sekali. Dalam culpa atau kelalaian ini, unsur terpentingnya adalah pelaku mempunyai kesadaran atau pengetahuan yang mana pelaku seharusnya dapat membayangkan akan adanya akibat yang ditimbulkan dari perbuatannya, atau dengan kata lain bahwa pelaku dapat menduga bahwa akibat dari perbuatannya itu akan menimbulkan suatu akibat yang dapat dihukum dan dilarang oleh undang-undang.

Maka dari uraian tersebut di atas, dapat dikatakan bahwa jika ada hubungan antara batin pelaku dengan akibat yang timbul karena perbuatannya itu atau ada hubungan lahir yang merupakan hubungan kausal antara perbuatan pelaku dengan akibat yang dilarang itu, maka hukuman pidana dapat dijatuhkan kepada si pelaku atas perbuatan pidananya itu.

\section{Bagaimanakah penerapan hukum antara perbuatan melawan hukum dengan perbuatan tindak pidana.}

Jika seseorang diduga memenuhi unsur-unsur tindak pidana, ada kemungkinan juga (meskipun tidak selamanya) unsur-unsur tersebut merupakan juga unsur-unsur perbuatan melawan hokum. Apabila terhadap 1 (satu) tindakan tersebut memenuhi unsur-unsur perbuatan melawan hokum maupun unsur-unsur tindak pidana, maka kedua macam sanksi dapat dijatuhkan secara berbarengan. Artinya, pihak korban dapat menerima ganti rugi perdata (dengan dasar gugatan perdata), tetapi juga pada waktu yang bersamaan (dengan proses pidana) pelaku dapat dijatuhkan sanksi pidana sekaligus. Karena itu tidak mengherankan jika kemudian ternyata bahwa beberapa perbuatan pidana juga merupakan perbuatan melwan hokum. Misalnya perbuatan pidana mengenai penyerangan orang, penahanan illegal,dan lain-lainnya.

Penerapan hokum antara perbuatan melawan hokum dengan perbuatan tindak pidana yang membedakannya hanya saja antara perbuatan pidana dengan perbuatan melawan hokum (perdata) adalah bahwa sesuai dengan sifatnya sebagai hokum publik, maka dengan perbuatan pidana, ada kepentingan umum yang dilanggar (di samping mungkin juga kepentingan individu), sedangkan dengan perbuatan melawan hokum (perdata) maka yang dilanggar hanya kepentingan pribadi saja.

Perbuatan Melawan Hukum (onrechtmatige daad) dalam konteks perdata diatur dalam Pasal 1365 Kitab Undang-Undang Hukum Perdata atau Burgerlijk Wetboek ("BW"), dalam Buku III BW, pada bagian "Tentang perikatan-perikatan yang dilahirkan demi Undang-Undang", yang berbunyi:

"Tiap perbuatan melanggar hukum, yang membawa kerugian kepada orang lain, mewajibkan orang yang karena salahnya menerbitkan kerugian itu, mengganti kerugian tersebut." Kata "perbuatan" meliputi perbuatan positif dan perbuatan negatif. Perbuatan positif adalah perbuatan yang benar-benar dikerjakan diatur dalam Pasal 1365 KUHPerdata. Perbuatan negatif adalah perbuatan yang benar-benar tidak dikerjakan, diatur dalam pasal 1366 KUHPerdata

Rumusan perbuatan positif dalam Pasal 1365 KUHPerdata dan perbuatan negatif dalam pasal 1366 KUHPerdata hanya digunakan sebelum ada putusan Hoge Raad Nederlands 31 januari 1919 karena pada waktu itu pengertian "melawan hukum" hanya bagi perbuatan positif, dalam arti sempit telah keluar Putusan Hoge Raad 31 januari 1919, pengertian "melawan hukum" diperluas, mencakup juga perbuatan negatif. Dalam putusan Hoge Raad Nederlands sebelum tahun 1919, pengertian melawan hukum masih menganut paham yang sempit, yang menyatakan pengertian dari perbuatan melawan hukum adalah :"perbuatan melawan hukum adalah suatu perbuatan yang, melanggar hak orang lain atau jika orang berbuat bertentangan dengan kewajiban hukumnya sendiri". Melalui tafsiran sempit ini banyak masyarakat yang dirugikan, tetapi tidak dapat menuntut apa-apa. 

berikut:

Beberapa defenisi lain yang pernah diberikan terhadap perbuatan melawan hukum adalah sebagai

1. tidak memenuhi sesuatu yang menjadi kewajiban sendiri selain dari kewajiban kotraktual atau kewajiban quasi contractual yang menerbitkan hak untuk mengganti rugi.

2. Suatu perbuatan atau tidak berbuat sesuatu yang mengakibatkan timbulnya kerugian bagi orang lain tanpa sebelumnya ada suatu hubungan hukum, kewajiban mana ditujukan terhadap setiap orang pada umumnya dan dengan tidak memenuhi kewajibannya tersebut dapat diminta suatu ganti rugi.

3. Tidak memenuihi suatu kewajiban yang dibebankan oleh hukum, kewajiban mana ditujukan terhadap setiap orang pada umumnya dan dengan tidak memenuhi kewajibannya tersebut dapat diminta suatu ganti rugi.

4. Suatu kesalahan perdata terhadap mana suatu ganti kerugian dapat dituntuk yang bukan merupakan wanprestasi terhadap kontrak, atau wanprestasi atas kewajiban trust, ataupun wanprestasi terhadap kewajiban equitylainnya.

5. Suatu kerugian yang tidak disebabkan oleh wanprestasi terhadap kontrak, atau lebih tepatnya, merupakan suatu perbuatan yang merugikan hak-hak orang yang diciptakan oleh hukum yang tidak tertib dari hubungan kontraktual.

6. Suatu perbuatan atau tidak berbuat sesuatu yang secara bertentangan dengan hukum melanggar hak orang lain yang diciptakan oleh hukum, dan karenanya suatu ganti rugi dapat dituntut oleh pihak yang dirugikan.

Agar suatu perbuatan dapat dikategorikan sebagai suatu perbuatan melawan hukum, maka harus memenuhi unsur-unsur perbuatan sebagai berikut:

1. Adanya suatu perbuatan. Suatu perbuatan melawan hukum diawali oleh suatu perbuatan dari si pelakunya. Perbuatan disini meliputi perbuatan aktif (berbuat sesuatu) maupun pasif (tidak berbuat sesuatu), padahal secara hukum orang tersebut diwajibkan untuk patuh terhadap perintah undangundang, ketertiban umum, dan kesusilaan (public order and morals).

2. Perbuatan tersebut melawan hukum. Manakala pelaku tidak melaksanakan apa yang diwajibkan oleh undang-undang, ketertiban umum dan atau kesusilaan, maka perbuatan pelaku dalam hal ini dianggap telah melanggar hukum, sehingga mempunyai konsekwensi tersendiri yang dapat dituntut oleh pihak lain yang merasa dirugikan.

3. Adanya kerugian bagi korban. Yang dimaksud dengan kerugian, terdiri dari kerugian materil dan kerugian immateril. Akibat suatu perbuatan melawan hukum harus timbul adanya kerugian di pihak korban, sehingga membuktikan adanya suatu perbuatan yang melanggar hukum secara luas.

4. Adanya hubungan kausal antara perbuatan dengan kerugian. Hubungan kausal merupakan salah satu ciri pokok dari adanya suatu perbuatan melawan hukum. Perbuatan melawan hukum dalam hal ini harus dilihat secara materiil. Dikatakan materiil karena sifat perbuatan melawan hukum dalam hal ini haru dilihat sebagai suatu kesatuan tentang akbat yang ditimbulkan olehnya terhadap diri pihak korban. Untuk hubungan sebab akibat ada2 (dua) macam teori, yaitu teori hubungan faktual dan teori penyebab kirakira. Hubungan sebab akibat (causation in fact) hanyalah merupakan masalah fakta atau apa yang secara faktual telah terjadi. Sedangkan teori penyebab kira-kira adalah lebih menekankan pada apa yang menyebabkan timbulnya kerugian terhadap korban, apakah perbuatan pelaku atau perbuatan lain yang justru bukan dikarenakan bukan suatu perbuatan melawan hukum. Namun dengan adanya suatu kerugian, maka yang perlu dibuktikan adalah hubungan antara perbuatan melawan hukum dengan kerugian yang ditimbulkan.

Berdasarkan rumusan Pasal 1365 KUHPerdata, dalam buku Hukum Perdata Indonesia karangan Prof. Abdulkadir Muhammad, S.H. mengemukakan unsur Perbuatan Melawan Hukum sebagai berikut :

1). Perbuatan itu harus melawan hukum (onrechtmatig);2).Perbuatan itu harus menimbulkan kerugian;

3).Perbuatan itu harus dilakukan dengan kesalahan; dan 4). Antara perbuatan dan kerugian yang timbul harus ada hubungan kausal.

Jika salah satu unsur-unsur diatas tidak terpenuhi, suatu perbuatan tidak dapat digolongkan kedalam perbuatan melawan hukum. Suatu perbuatan dikatakan melawan hukum apabila orang tersebut melanggar undang-undang yang ditetapkan oleh hukum.oleh karena itu tidak semua tindak pidana merupakan perbuatan melawan hukum karena ada alasan pembenar, berdasarkan pasal 50, pasal 51 KUHP. Sifat dari melawan hukum itu sendiri meliputi : a).Sifat formil yaitu bahwa perbuatan tersebut diatur oleh undang-undang.

b). Sifat materiil yaitu bahwa perbuatan tersebut tidak selalu harus diatur dalam sebuah undang-undang tetapi juga dengan perasaan keadilan dalam masyarakat. 
Perbuatan melawan hukum dapat dibedakan menjadi :

1. Fungsi negatif yaitu mengakui kemungkinan adanya hal-hal diluar undang-undang dapat menghapus sifat melawan hukum suatu perbuatan yang memenuhi rumusan undang-undang.

2. Fungsi positif yaitu mengakui bahwa suatu perbuatan itu tetap merupakan tindak pidana meskipun tidak dinyatakan diancam pidana dalam undang-undang, apabila bertentangan dengan hukum atau aturanaturan yang ada di luar undang-undang.

Sifat melawan hukum untuk yang tercantum dalam undang-undang secara tegas haruslah dapat dibuktikan. Jika unsur melawan hukum dianggap memiliki fungsi positif untuk suatu delik maka hal itu haruslah dibuktikan. Jika unsur melawan hukum dianggap memiliki fungsi negative maka hal itu tidak perlu dibuktikan.

Sementara itu penerapan hukum dalam perbuatan tindak pidana dapat dilihat dalam beberapa unsur yaitu unsur formil dan unsur materil. Unsur formil yaitu: Perbuatan manusia, dalam arti luas, artinya tidak berbuat yang termasuk perbuatan dan dilakukan oleh manusia yaitu:

a. Melanggar peraturan pidana. dalam artian bahwa sesuatu akan dihukum apabila sudah ada peraturan pidana sebelumnya yang telah mengatur perbuatan tersebut, jadi hakim tidak dapat menuduh suatu kejahatan yang telah dilakukan dengan suatu peraturan pidana, maka tidak ada tindak pidana.

b. Diancam dengan hukuman, hal ini bermaksud bahwa KUHP mengatur tentang hukuman yang berbeda berdasarkan tindak pidana yang telah dilakukan.

c. Dilakukan oleh orang yang bersalah, dimana unsur-unsur kesalahan yaitu harus ada kehendak, keinginan atau kemauan dari orang yang melakukan tindak pidana serta Orang tersebut berbuat sesuatu dengan sengaja, mengetahui dan sadar sebelumnya terhadap akibat perbuatannya. Kesalahan dalam arti sempit dapat diartikan kesalahan yang disebabkan karena si pembuat kurang memperhatikan akibat yang tidak dikehendaki oleh undang-undang.

d. Pertanggungjawaban yang menentukan bahwa orang yang tidak sehat ingatannya tidak dapat diminta pertanggungjawabannya. Dasar dari pertanggungjawaban seseorang terletak dalam keadaan jiwanya.

Unsur material dari tindak pidana bersifat bertentangan dengan hukum, yaitu harus benar-benar dirasakan oleh masyarakat sehingga perbuatan yang tidak patut dilakukan. Jadi meskipun perbuatan itu memenuhi rumusan undang-undang, tetapi apabila tidak bersifat melawan hukum, maka perbuatan itu bukan merupakan suatu tindak pidana. Unsur-unsur tindak pidana dalam ilmu hukum pidana dibedakan dalam dua macam, yaitu unsur objektif dan unsur subjektif. Unsur objektif adalah unsur yang terdapat di luar diri pelaku tindak pidana. Unsur ini meliputi:

a. Perbuatan atau kelakuan manusia, dimana perbuatan atau kelakuan manusia itu ada yang aktif (berbuat sesuatu), misal membunuh (Pasal 338 KUHP), menganiaya (Pasal 351 KUHP).

b. Akibat yang menjadi syarat mutlak dari delik. Hal ini terdapat dalam delik material atau delik yang dirumuskan secara material, misalnya pembunuhan (Pasal 338 KUHP), penganiayaan (Pasal 351 KUHP), dan lain-lain.

c. Ada unsur melawan hukum. Setiap perbuatan yang dilarang dan diancam dengan pidana oleh peraturan perundang-undangan hukum pidana itu harus bersifat melawan hukum, meskipun unsur ini tidak dinyatakan dengan tegas dalam perumusan.

Sementara itu unsur subyektif dari Tindak pidana meliputi :

a. Kesengajaan (dolus), dimana hal ini terdapat di dalam pelanggaran kesusilaan (Pasal 281 KUHP), perampasan kemerdekaan (Pasal 333 KUHP), pembunuhan (Pasal 338).

b. Kealpaan (culpa), dimana hal ini terdapat di dalam perampasan kemerdekaan (Pasal $334 \mathrm{KUHP}$ ), dan menyebabkan kematian (Pasal 359 KUHP), dan lain-lain.

c. Niat (voornemen), dimana hal ini terdapat di dalam percobaan atau poging (Pasal 53 KUHP)

d. Maksud (oogmerk), dimana hal ini terdapat dalam pencurian (Pasal 362 KUHP), pemerasan (Pasal 368 KUHP), penipuan (Pasal 378 KUHP), dan lain-lain

e. Dengan rencana lebih dahulu (met voorbedachte rade), dimana hal ini terdapat dalam membuang anak sendiri (Pasal 308 KUHP), membunuh anak sendiri (Pasal 341 KUHP), membunuh anak sendiri dengan rencana (Pasal 342 KUHP). 


\section{SIMPULAN}

1. Sesuatu perbuatan dikatakan melawan hukum apabila perbuatan itu masuk dalam rumusan delik sebagaimana dirumuskan dalam undang-undang. Hanya saja yang membedakan antara perbuatan pidana dengan perbuatan melawan hukum (perdata) adalah bahwa sesuai dengan sifatnya sebagai hokum publik, maka dengan perbuatan pidana, ada kepentingan umum yang dilanggar (di samping mungkin juga kepentingan individu), sedangkan dengan perbuatan melawan hukum (perdata) maka yang dilanggar hanya kepentingan pribadi saja.

2. Sifat melawan hukum untuk yang tercantum dalam undang-undang secara tegas haruslah dapat dibuktikan. Jika unsur melawan hukum dianggap memiliki fungsi positif untuk suatu delik maka hal itu haruslah dibuktikan. Jika unsur melawan hukum dianggap memiliki fungsi negative maka hal itu tidak perlu dibuktikan. Sementara itu penerapan hukum dalam perbuatan tindak pidana dapat dilihat dalam beberapa unsur yaitu unsur formil dan unsur materil.

\section{DAFTAR PUSTAKA}

\section{Buku-buku}

A Moegni Djojodirdjo, 1982. Perbuatan Melawan Hukum, Pradnya Paramita, Jakarta

Adami Chazawi, 2002. Pengantar Hukum Pidana Bag 1, Grafindo, Jakarta

Erdianto Efendi, 2011. Hukum Pidana Indonesia. Suatu Pengantar. PT Refika Aditama: Bandung.

Munir Fuady, 2002. Perbuatan Melawan Hukum: Pendekatan Kontemporer .PT. Citra Aditya Bandung

Bakti, M.A Moegni Djojodirdjo, 1984. Perbuatan Melawan Hukum, Pradnya Paramita, Jakarta

R. Wirjono Prodjodikoro, 1984. Perbuatan Melawan Hukum,: Sumur Bandung, Bandung

Roni Wiyanto.2012. Asas-asas Hukum Pidana Indonesia. C.V.Mandar Maju Bandung.

P.A.F Lamintang, 1999. Dasar-Dasar Hukum Pidana Indonesia,: PT Citra Aditya Bakti, Bandung

\section{B. Perundang-undangan}

\section{Kitab Undang-Undang Hukum Perdata}

Putusan Mahkamah Agung Belanda dalam kasus Arrest Cohen-Lindenbaum (H.R. 31 Januari 1919) ini telah menjadi yurisprudensi dan sudah diketahui umum telah juga menjadi rujukan bagi hukum di Indonesia. 